\title{
Anti-Corruption Declaration as a Measure of Control for the Activities of Subjects of Public Authorities
}

\author{
Liudmila Kornuta $^{1 *}$, Tetiana Goloyadova ${ }^{1}$, Yuliia Zavhorodnia ${ }^{2}$, Yurii Reva ${ }^{1,3}$ \\ 'Department of Administrative and Financial Law, National University "Odesa Law Academy", Odessa, Ukraine \\ ${ }^{2}$ Department of Political Theories, National University "Odesa Law Academy", Odessa, Ukraine \\ ${ }^{3}$ Directorate for Strategic Planning and European Integration of the Ministry of Justice of Ukraine, Kyiv, Ukraine
}

Received: 18/06/2019

Accepted: 27/09/2020

Published: 20/12/2020

\begin{abstract}
The article is devoted to the study of anti-corruption declaration in Ukraine, which is at the stage of institutionalization and practical improvement. The aim of the article is to establish possible ways to increase the effectiveness of the anti-corruption declaration mechanism, taking into account socio-economic conditions based on the use of international experience in this process; to define a single concept of the humanization of the financial control and identify specific recommendations for reforming the existing system of anticorruption mechanism in Ukraine. In carrying out this study, general and special methods of scientific knowledge were used: the system analysis method, the dialectic method, the formal logical method and the structural-functional method, as well as a number of empirical methods. The authors came to the conclusion that the mechanism of anti-corruption declaration in Ukraine was formed taking into account the socio-economic prerequisites for counteracting corruption and international trends in the implementation of financial control. To increase the positive effect of the introduction of anti-corruption declaration, it is important to know the approach chosen for exercising financial control over the subjects of public administration. The article may be useful for the relevant subjects of public administration for the further improvement of socially sensitive anti-corruption tools. It may also be useful for researchers of social and legal processes related to the development of civil society. An analysis of the processes of management transformation in the country and in the world facilitated to identify problems that require special attention and find solutions for the implementation of project activities to create a modern management structure for electronic filing of declarations. The novelty and originality of the study lies in the fact that the article reveals the fundamental determinants of anti-corruption declaration taking into account the development trends of public administration.
\end{abstract}

Keywords: Corruption, Humanization, Anti-corruption declaration, Subject of public authority, Financial control, International standards

\section{Introduction}

Corruption as a system of negative relations has become one of the most acute problems in the modern society, not only because it is evidence of the degradation of the moral foundations of society, but also because it entails negative consequences for the development of most areas of the management, economics and industry. The fight against corruption must be carried out simultaneously through the prevention and enforcement. Both elements are complementary and interchangeable. The state's policy on preventing and combating corruption is aimed at ensuring the spread of intolerance to corruption in society, creating conditions under which social partnership between the state and the population will develop, possibly through the use of consistent, planned and coordinated actions, since systemic phenomena require a systematic approach to overcome them [1]. The lack of consistency in the actions of the authorities to implement the anti-corruption policy has become one of the reasons for the improper implementation of the National Anti-Corruption Strategy for 2011-2015 as the main program document in the anti-corruption field [2].
The state anti-corruption policy of Ukraine should be aimed at creating and organizing an effective system not only for identifying prerequisites, preventing, counteracting, but also eliminating the consequences of corruption acts, promoting the identification of corruption acts in the behaviour and life of persons who are subject to the obligation of financial control. One of the ways to identify and prevent corruption is financial control, which is implemented through anti-corruption declaration, including. Under anti-corruption declaration it is understood a method of checking the integrity of persons authorized to fulfill the functions of the state and local selfgovernment. In this case, it is necessary to use a broad interpretation of the declaration, based solely on the purpose of its use in the fight against corruption. Therefore, such a feature of declaration as an electronic nature is not basic. It is the designation of the choice of submitting a declaration - via electronic form. At the same time, this feature is inherent in declaring as a method of financial control in Ukraine. Only in 1995, with the adoption of the first Law of Ukraine "On Combating Corruption", the declarationwas institutionalized as an instrument of financial control, but exclusively for persons authorized to fulfill state functions. In addition, information on

Corresponding author: Liudmila Kornuta, Department of Administrative and Financial Law, National University "Odesa Law Academy”, Odessa, Ukraine. E-mail: kornuta02@gmail.com 
income, securities, real estate and valuable property and deposits in the banks of officials and members of their families began to undergo annual publication in official publications of state bodies of Ukraine [3]. Further, the declaration procedure was determined by the Resolution of the Cabinet of Ministers of Ukraine of August 11, 1995 № 641 "On the application of Article 13 of the Law of Ukraine"On State Service". On the positive side, the declaration requirement concerned both persons holding state service positions and those applying for it. The data in the declarations concerned income, financial liabilities, property owned. However, all the information contained in the declarations was confidential.

Separately, it should be noted that the declarant's failure to submit or provision of incomplete or false information about income, financial liabilities andproperty condition automatically turned into a basis for the termination of state service, as well as bringing to administrative responsibility. The need to reassess anti-corruption declaration is mediated by the introduction of innovative technology for electronic filing of declarations, on the one hand, and the introduction of public administration, on the other, as it is planned to develop a new style of resource provision of public authorities with highly professional servants who act exclusively to protect public interests.

\section{Methodological Framework}

The issues of anti-corruption declaration in Ukraine are relevant, however, there is currently no comprehensive study, firstly, of assessing the influence of socio-economic factors of corruption on the choice of the concept of anti-corruption, and, secondly, of determining the further development of financial control mechanisms.

In the research process, the following methods were used: theoretical, empirical, structural and system analysis, statistical and economic methods, expert assessment methods, general scientific methodology. Theoretical methods (analysis, synthesis) made it possible to identify the institutional and legal foundations of the anti-corruption declaration, to consider the selected approaches to financial control in their unity, to present the factor basis for combating corruption in Ukraine. Empirical methods have created the basis for the development of a set of measures for the development of electronic anti-corruption declaration.

The key to identifying trends in the institutionalization of anti-corruption declarations is the identification of corruption risks and their elimination. From this position, a formal dogmatic approach was used, in which thelaw-governed state does not oppose the civil society, but creates favourable conditions for its normal functioning and development, while exercising financial control over the activities of public authorities using various methods. Despite the obvious relevance of the real, rather than the formal significance of the declaration, it should be recognized that domestic scientists resort only to fragmented studies of these issues. At the same time, it is insufficient to study the existing world practices of financial control.

In this article the issues of anti-corruption declaration as a systemic tool to combat corruption in Ukraineare first investigated. For consistent coverage of the problem, substantive blocks have been identified characterizing a homogeneous group of public relations, which concern the definition of the essence of anti-corruption declaration, namely: the definition of corruption as a measure of corruption counteraction, the institutional and legal framework of anticorruption declaration, international standards and foreign experience in financial control over the functioning of public authorities.

\section{Results and Discussions \\ 3.1 Anti-Corruption Declaration as an Anti-Corruption Measure}

The origins of corruption are laid in the negative features of human behaviour, which give rise to establish a special system of connections and relations in order to obtain and distribute illegal income. For this purpose, both gaps in the legislation that provoke the spontaneous appearance of normatively unregulated additional activities, as well as direct violations of existing norms and rules are used. Such a system consists regardless of the degree of the development of the society and the economic relations. From the point of view of the interests of the society, the question is only in the scale of this phenomenon. Upon reaching a certain valuethe level of corruption, which is measured by the degree of public confidence in the authority, the society actually remains without effective management. Thus, there is a real threat to the existence of society itself and the fight against corruption is considered one of the priority tasks of a significant number of states.

Anyone with discretionary power - the power, at its discretion, to allocate certain resources that do not belong to it, can be exposed to corruption. At the same time, the main incentive for corruption is the possibility of obtaining economic profits (benefits) connected with the use of authoritative powers, and the main limiting factor is the risk of exposure and punishment. Economic factors of corruption at the level of social prerequisites are connected with the economic crisis, which led to the deformation of socio-economic relations and caused severe economic consequences for Ukrainian society, the state and the vast majority of citizens. Property inequality and lack of effective control in the distribution of income, poverty, unemployment, outflow of productive forces abroad, and many other economic problems of modern Ukraine have led to an increase in the number of offenses, including corruption.

Despite a common goal, the prevention of corruption has a different manifestation, tools and methods, depending on the direction of the public sector or the private one. In the framework of this study, it is advisable to pay attention to the prevention of corruption in the public sector, which can be defined as the totality of public relations arising from the nonadmission, prevention and assistance in identifying the signs of corruption and the violations of anti-corruption requirements, prohibitions, restrictions in the performance of the functions of the state or local government. It is worth to mark out that effective corruption counteraction requires a systematic approach and the use of integrated measures, including scientific, strategy and tactics of counteraction.

Corruption in Ukraine over the entire existence of an independent state has become perhaps the most important problem in social and state development, it has a deforming effect on the system of public administration, ensuring the welfare of the population, the development of national capital, etc. In this regard, the state takes active measures of counteraction and prevention of the corruption. This is primarily reflected in the adoption of the Law of Ukraine "On Prevention of Corruption", the introduction of anti-corruption programs (state and departmental), the aggravation of criminal liability for corruption crimes, the creationof specialized anticorruption bodies - the National Agency for the Prevention of Corruption, the National Anti-Corruption Bureau, Specialized anti-corruption prosecutors and the like.

In general, the anti-corruption mechanism includes a set of restrictions and obligations for public servants who collectively create a primary frontier of corruption prevention, which is appealed to preventively protect society from corruption 
offenses. Its immediate goal is not to bring to the criminal liability, but to prevent the occurrence of corruption (unlawful communication with individuals, material or moral dependenceof public servant, etc.) [4]. Anti-corruption declaration arises basing on the provisions of the LawOf Ukraine "On Prevention of Corruption", and is one of the means of financial control implementationin relation to persons authorized to perform functions of thestate or local selfgovernment, along with monitoring the lifestyle of subjectsdeclarations and additional measures of financial control [5]. The introduction of anti-corruption declaration not only contributes to the fight against corruption, but also increases the level of public confidence in law enforcement bodies. The population must be sure that they competently and honestly carry out their activities in accordance with the requirements of the law. It should be noted that the use of anticorruption declaration contributes to the achievement of the following main goals: increasing the level of transparency of law enforcement agencies and the trust of citizens; prevention of conflict of interest and its settlement in case of occurrence, which allows to ensure a high level of good behaviour of a law enforcement officer; controlling the changes in the assets of certain law enforcement officers in order to prevent them from committing certain unlawful corruption actions, which, in turn, will protect them from unfounded accusations and revealing the facts of illegal enrichment, other unlawful activities by providing relevant supporting documents and other evidence.

\subsection{Institutional and Legal Foundations of Anti-Corruption Declaration in Ukraine}

With the change in approaches to public service, the approach to anti-corruption activities has also changed. Accordingly, in the Law of Ukraine "On the Principles of Prevention and Combating Corruption" of 2011 for the first time it was defined the subject of declaration as a person who is obliged to file a declaration of property, income, expenses and financial obligations; declarations are subject to disclosure, and disciplinary liability may be applied for violation of the declaration requirements [6]. Since 2014, the anti-corruption declaration has changed: the entities responsible for declaring also include those charged with local self-government functions, the way of submitting the declaration has also changed - by completing the declaration on the official website of the National Agency [5]. In Ukraine, a system of anticorruption declaration has been selected, which is characterized by the following features: 1) the object of the declaration is illegal enrichment, which is manifested in information about the financial position of the declaration; 2) the declaration form is possible both electronic and paper; 3 ) the declaration system is the same for all branches of government; 4) the fundamentals of the legal regulation of public relations, which are associated with anti-corruption declarations, are defined by the legislation on state service and a separate anti-corruption law governing the common sphere of preventing corruption; 5) declarations whose persons are authorized to perform the functions of the state and local self-government are in the public domain; and 6) the declaration is characterized by an external type of institutional support for the declaration through the functioning of specialized anti-corruption bodies.

To introduce innovations regarding the declaration into practical activities, a transitional period was established for the start of the electronic declaration system. The system for filing and publishing declarations of persons authorized to perform the functions of the state or local self-government, began its work in two stages [7]. Regarding the allocation of types of electronic anti-corruption declaration under the legislation of Ukraine, the gradation can be carried out on the basis of the following criteria: depending on the subject of declaration, depending on the object of declaration, depending on the frequency of declaration. Based on the fact that anti-corruption declaration is a means of financial control, which belongs to the mechanism of prevention and counteraction to corruption, the subjects providing anti-corruption declaration belong to the system of subjects of counteraction to corruption. At the same time, the peculiarity of the system of subjects of anti-corruption declaration is that the same subject will be both the one that provides the possibility of anti-corruption declaration and the subject that is obliged to submit a declaration of persons authorized to perform state and local self-government functions.

The object of anti-corruption declaration is the income and property of the subjects who are authorized to perform the functions of the state and local self-government. There is no body that is authorized exclusively to administer anticorruption declarations, but there is a multi-purpose body - the National Agency for Prevention of Corruption, which is responsible for ensuring the formation and implementation of state anti-corruption policy. It is advisable to classify subjects that ensure the implementation of anti-corruption declarations, depending on their functional purpose in this area, into: 1) subjects authorized to establish the legal framework for the implementation of anti-corruption declarations (Verkhovna Rada of Ukraine, President of Ukraine, National Council for Anti-Corruption Policy, Cabinet of Ministers of Ukraine); 2) subjects authorized to control the timely submission of declarations of persons authorized to perform the functions of the state and local self-government (National Agency for Prevention of Corruption, authorized units (authorized persons) for the prevention and detection of corruption, internal control unit of the National Agency [5, 8]; 3) subjects authorized to exercise control over the correctness and completeness of filling out declarations, logical and arithmetic control (National Agency for the Prevention of Corruption).

Public control over activities related to anti-corruption declaration is carried out through the Public Council under the National Agency, which is established and formed by the Cabinet of Ministers of Ukraine of 15 people based on the results of the competition. In addition, to especially unauthorized entities that have the ability to control the contents of declarations through open access to their contents, the civil society institutions and individual citizens are usually included. Formally, civil society institutions include: public associations, trade unions and their associations, creative unions, organizations of employers and their associations, charitable and religious organizations, bodies of selforganization of the population, non-governmental media and other non-entrepreneurial societies and institutions legalized in accordance with the law [9].

\subsection{International Standards of Financial Control over the Functioning of Public Authority}

The role of financial control as an anti-corruption measure has increased since the 1990s, when the UN Resolution "On Practical Measures to Combat Corruption" was adopted, emphasizing the importance of introducing anti-corruption measures. At the same time, there has been more than just the spread of declarations in transition countrieseconomy, but also the emergence of mainly recommended for this international standards [10].

One of the first international instruments to make the anticorruption declaration mandatory is the Inter-American Convention against Corruption, adopted in 1996. In this document, corruption is defined as a factor that undermines the legitimacy of public institutions and strikes at society, its moral 
foundations and justice, as well as the comprehensive development of people. In overcoming the corruption, Member States are encouraged to implement preventive measures. One such measure is the introduction of a system for recording the profits, assets and obligations of persons holding public office in certain positions, as required by law, and, where appropriate, making such cases public [11].

The rules on declaration are in fact duplicated in the International Code of Conduct for Public Officials. The declaration requirement is worded as follows: "public officials, in accordance with their official position and, as permitted or required by the law and administrative regulations, comply with the requirements to disclose or communicate information on personal assets and liabilities and, where possible, information on assets and liabilities of the spouse and / or dependents". That is, there is a requirement to declare the income of the spouse and / or dependents, which is a progressive step in the field of declaration [12].

An important step towards the implementation of the declaration was the adoption of the Lima Convention in 1997. This international document expanded the requirements for civil servants, so it is proposed to introduce a system of income declarations for elected officials (and their families) and oblige them to explain income growth exceeding legal sources of income. In addition, it is necessary to introduce temporary or permanent control of the income and expenditure of decisionmakers in the public sector (as well as their families and colleagues) with the help of an independent agency, where it is possible [13].

It was during this period that, along with paper declarations, electronic ones began to exist. The OECD study showed that countries in which declarations began to be accepted not in paper form, but in electronic form, as a result received an increase in the reliability of the data provided on average from $67 \%$ to $98 \%$ in the first two years. Currently, more than 100 countries around the world have electronic declaration systems, which has occurred due to the promotion of this phenomenon by the United Nations and western countries.

In 2000, the EU Council adopted a recommendation on codes of conduct for state servants. The specified international document defines the obligation to submit declarations by persons holding positions in the state service. The purpose of the declaration is defined as control over the conflict of interests, and not the issue of unjust enrichment [14]. The turning point in the declaration as a form of financial control in the field of anti-corruption was marked by the adoption of the UN Convention against Corruption in 2003, which uses a broader approach to the interpretation of financial control and the persons to whom it is applied, which will be discussed in the following parts of this study [15]. It appears that the convention defines a flexible declaration mechanism, which is detailed in the Technical Guide to the UN Convention. General provisions on declaring can be defined as follows: promulgation should cover all significant types of income and assets of officials; a disclosure form should create the conditions for the possibility of comparing the financial situation of officials in chronological progression; officials must be given the duty to ground the virtue of their sources of income; there should be an effective system of control and supervision, etc. [16]. Thus, despite the fact that the aforementioned international documents did not have binding legal force, all recommendations in one way or another were introduced into the national legislation of most states.

\subsection{International Practice of Anti-Corruption Declaration}

The choice of practice of anti-corruption declaration at the international level depends on the type of legal system of the state, state structure, level of development of the management system, the intensity of involvement of civil society institutions in public administration, archetypes of socio-cultural development and the like. It is impossible to consider the practice of declaring each individual state, since this should be the subject of a separate scientific study. Moreover, there will be no tangible effect for the purposes of this study. Therefore, it is advisable to focus on the main approaches to declaring, their positive and negative characteristics and highlighting the experience, which is useful for the Ukrainian state. The anticorruption declaration system as a tool to prevent corruption within the framework of a single anti-corruption regime differs depending on the object: 1) declaration of a conflict of interest; 2) declaration of property status; and 3) declaration of a conflict of interest and property status.

In the first case, the main purpose of the declaration is preventive, while in others it is both preventive and punitive. The conflict of interest exists when a public servant can use his official position for personal gain or for the benefit of other private individuals, but does not have to. In other words, identifying a potential conflict of interest is not an indicator of inappropriate behaviour, but rather a warning of its potential. A declaration system of conflict of interest operates to identify potential or actual conflicts before they occur. In general, the conflict of interest declaration system has been used in the practice of preventing corruption in states such as Argentina, Croatia, China, the USA, etc. [17]. In declaration systems that focus on identifying and preventing illicit enrichment, declarations are designed to collect information that will allow to control the information about official wealth to identify any unusual assets or income that are not related to wages or any other legitimate source of income. This is important in countries where the perception of corruption and impunity is high. The main corruption actions, which are usually associated with illicit enrichment, are bribery and embezzlement. To identify and bring to criminal liability both types of crimes, many jurisdictions decided to use a declaration system that focuses on detecting illicit enrichment by monitoring and declaring significant changes in the property status of state servants that cannot be explained legally. To be effective, the illicit enrichment declaration system must pose a real threat of detection. Therefore, an important aspect of functioning is the ability to verify declarations through agencies investigating internal affairs, civil society institutions (if declarations are published), cross-checking of the declaration income statements and assets (tax and banking information, registers of vehicles and real estate, etc., cross-checking differences between the chosen lifestyle and actual income, etc.) [18-19]. For example, in Turkey, the content of the declaration focuses on unexplained variations of wealth, sources of income, investment and liabilities, as well as property data. In addition, the system of declaring property status is used in Indonesia, Guatemala, Mongolia [20].

The third approach to the declaration system is dualistic. Despite a clear distinction between illicit enrichment and conflict of interest, many declaration systems combine elements of both. This combination allows you to cover the criteria for checking content regardless of whether conflicts of interest or cases of illicit enrichment are being reviewed. However, these criteria may be present in by-laws, procedural guidelines, or agency regulations that are defined for small groups of officials (for example, customs). This declaration system, for example, is implemented in the practice of Brazil and Slovenia.

The experience of the US anti-corruption declaration is exceptional, the main purpose of which is to identify and prevent potential conflicts of interest. The declaration system is 
not designed specifically to combat illicit enrichment. In the US, there are differences between the form of the declaration, which is subject to publication and which is confidential. The form that is to be made public does not require asset value categories and income amounts, and does not require financial interests (including salaries, consultations, fees, equity stakes, interests in tangible or personal property, dividends, royalties, rents, capital gains, intellectual property income, etc.)

Thus, the key elements of the US declaration system are: a direction to identify and prevent potential conflicts of interest; a financial disclosure is carried out to demonstrate government transparency; the declarations are submitted to the institution in which the declarant works; the information presented is checked for completeness and in fact, a potential conflict of interest (in case of violations, ethics officers are intended to transfer this matter to the Office of the Inspector General, the Federal Bureau of Investigation or the public virtue department of the Ministry of Justice); agencies can choose to submit electronic or paper submissions; each agency is responsible for disclosing the income and assets of its employees, which should be available at the request of the public within 30 days after the submission of the final report; criminal, civil and administrative sanctions may be applied for submitting false information; the fee for late submission of the declaration is 200 US dollars if it is submitted within 30 days after the deadline; declarations are kept for six years after submission, except in cases of ongoing investigation [21].

It is proposed to use the experience of the United States to improve the system of anti-corruption declaration in terms of introducing control over the virtue of public servants at the local level. Adapting this provision to the legal system of the Ukrainian state,it is advisable to create an ethics commission within the system of the executive branch, legislative branch, and judicial branch. The powers of these commissions should include initial monitoring of compliance with anti-corruption laws, initial verification of declarations, receipt and consideration of allegations of possible violation of virtue by public servants of the relevant branch of government. For other entities that are subject to declaration, then for them the declaration procedure remains unchanged. It is also advisable to use penalties for late submission of declarations, if the period does not exceed 30 days. Such a measure will at the same time help to reduce the burden on trial courts, which are related to the late submission of declarations and will allow disciplining public servants under pressure of property encumbrances. Funds received as a fine can be used to develop the material and technical support of the declaration system.

\section{Conclusion}

The democratic transformation in Ukraine is directly or indirectly related to the fight against corruption. Attention is focused on the importance and progressiveness of the electronic anti-corruption declaration system as a mechanism of the state anti-corruption policy, which acts as a way of checking the integrity of persons authorized to perform state and local selfgovernment functions. It has been established that Ukraine has chosen a system of anti-corruption declaration, which is characterized by the following features: the object of the declaration is illegal enrichment, which is manifested in the information about the financial position of the declaration; the declaration form is possible both electronic and paper; the declaration system is the same for all branches of government; the fundamentals of the legal regulation of public relations, which are associated with anti-corruption declarations, are defined by the legislation on state service and a separate anticorruption law governing the common sphere of preventing corruption; declarations of persons authorized to perform the functions of the state and local self-government are in the public domain; the process of declarationis characterized by an external type of institutional support for declarations through the functioning of specialized anti-corruption bodies.

The following ways to improve the functioning of the anticorruption declaration system in Ukraine are proposed: return to the wording of the Law "On Prevention of Corruption" in terms of determining the minimum threshold for valuable movable property to be declared at a level of at least 50 minimum living wages for able-bodied citizens; adoption of a separate regulatory act that will determine the procedure for interaction between the National Agency for the Prevention of Corruption and other anti-corruption and law enforcement agencies with regard to combating corruption crime in Ukraine; the introduction in Ukraine of the obligatory annual declaration by citizens of their income to the tax service; identifying the reasons and taking measures to enhance the effectiveness of the National Agency for the Prevention of Corruption in the system of electronic declaration and legal framework for public participation in public administration require appropriate legal support.

\section{Ethical issue}

Authors are aware of, and comply with, best practice in publication ethics specifically with regard to authorship (avoidance of guest authorship), dual submission, manipulation of figures, competing interests and compliance with policies on research ethics. Authors adhere to publication requirements that submitted work is original and has not been published elsewhere in any language.

\section{Competing interests}

The authors declare that there is no conflict of interest that would prejudice the impartiality of this scientific work.

\section{Authors' contribution}

All authors of this study have a complete contribution for data collection, data analyses and manuscript writing.

\section{References}

[1] Komisarov OH, Kobzar OF. Zahal'ni zasady formuvannya antykoruptsiynoyi polityky. Realizatsiya derzhavnoyi antykoruptsiynoyi polityky v mizhnarodnomu vymiri: materialy IV Mizhnar. nauk.- prakt. konf. Kyyiv: Nats. akad. vnutr. Sprav.2019.

[2] Pro Natsional'nu antykoruptsiynu stratehiyu na 2011-2015 roky. Ukaz Prezydenta Ukrayiny vid 21.10.2011 r. Ofitsiynyy visnyk Prezydenta Ukrayiny, 29. St. 13. 2011.

[3] Pro borot'bu z koruptsiyeyu. Zakon Ukrayiny vid 05.10.1995 № 356/95-VR. Vidomosti Verkhovnoyi RadyUkrayiny, 34, 266276. (vtratyv chynnist' vid 05.01.2011). 1995.

[4] Mykhaylenko DH. Protydiya koruptsiynymzlochynamzasobamy kryminal'noho prava: kontseptual'ni osnovy. Odesa: Vydavnychyy dim «Hel'vetyka».2017.

[5] Pro zapobihannya koruptsiyi. Zakon Ukrayiny vid 14.10.2014 r. № 1700-VII. Ofitsiynyy visnyk Ukrayiny, 87, St. 156. 2014.

[6] Pro zasady zapobihannya i protydiyi koruptsiyi. Zakon Ukrayiny vid 07.04.2011 r. № 3206-VI (vtratyv chynnist' vid 01.09.2016) URL: https://zakon.rada.gov.ua/laws/show/3206-17. 2011.

[7] Pro pochatok roboty systemy podannya ta oprylyudnennya deklaratsiy osib, upovnovazhenykh na vykonannya funktsiy derzhavy abo mistsevoho samovryaduvannya. Rishennya nazapobihannya koruptsiyi vid 10.06.2016 № 2 Ofitsiynyy visnyk Ukrayiny, 55, St. 136. 2016.

[8] Typove Polozhennya pro upovnovazhenyy pidrozdil (osobu) z pytan' zapobihannya ta vyyavlennya koruptsiyi. Postanova Kabinetu Ministriv Ukrayiny vid 4 veresnya 2013 r. № 706. URL: https://www.kmu.gov.ua/npas/246722378. 2013. 
[9] Pro zatverdzhennya Poryadku spryyannya provedennyu hromads'koyi ekspertyzy diyal'nosti orhaniv vykonavchoyi vlady. Postanova Kabinetu Ministriv Ukrayiny vid 5 lystopada 2011 r. № 976. Ofitsiynyy visnyk Ukrayiny, 86, St. 100. 2008.

[10] Rezolyutsiya OON. «Praktychni zakhody iz borot'by z koruptsiyeyu». URL: https://documentsddsny.un.org/doc/UNDOC/GEN/N90/850/57/pdf/N9085057.pd f ? OpenElement. 1990.

[11] Konventsiya OON. Mizhamerykans'ka konventsiya proty koruptsiyi (pryynyata na tretiy plenarniy sesiyi 29 bereznya 1996) Konventsiya OON vid 29.03.1996. URL: https://zakon.rada.gov.ua/laws/show/998_089.1996.

[12] Mizhnarodnyy kodeks povedinky derzhavnykh posadovykh osib. Mizhnarodnyy dokument vid 23.07.1996 URL: https://zakon.rada.gov.ua/laws/show/995788. 1996.

[13] Lims'ka konventsiya. Deklaratsiya OON vid 11.09.1997. URL: https://zakon.rada.gov.ua/laws/show/998_090. 1997.

[14] Recommendation of the Committee of Ministers to Member states on Code of conduct for public officials. 10 of the Committee of Ministers to Member states on Code of conduct for public officials. URL: https://rm.coe.int/16806cclec. 2000.

[15] Konventsiya OON. Konventsiya Orhanizatsiyi Ob'yednanykh Natsiy proty koruptsiyi: Konventsiya OON vid 31.10.2003. URL: https://zakon.rada.gov.ua/laws/show/995_c16. 2003.

[16] Technical guide. Technical guide to the United Nations convention against corruption. URL:https://www.unodc.org/documents/corruption/Technical_ Guide UNCAC.pdf. 2019.

[17] Public Office, Private Interests. Accountability through Income and Asset Disclosure. 2012 International Bank for Reconstruction and Development. International Development Association or The World Bank. URL: https://star.worldbank.org/sites/star/files/Public\%20Office\%20Private\%20Interests.pdf. 2012.

[18] Income and asset declarations in practices Regional School of Public Administration. URL: file://C:/Users/User/Downloads/Comparativ e\%20stud y\%20$\% 20$ Income $\% 20$ and $\% 20$ asset $\% 20$ declarations $\% 20$ in $\% 20$ practi ce\%20-\%2 0web\%20(2).pdf. 2013.

[19] Khairullina ER, Bogdanova VI, Slepneva EV, Nizamutdinova GF, Fatkhullina LR, Kovalenko YA, Skutelnik OA. Global climate change: Cyclical nature of natural and permanent nature of man-made processes. EurAsian Journal of BioSciences, 2019;13(2):2311-2316.

[20] Bundesministerium der Justiz und für Verbraucherschutz. Good practices in asset disclosure systems in G20 countries. URL: https://www.bmjv.de/SharedDocs/Downloads/EN/G20/Good\% 20practices $\% 20$ in $\% 20$ asset $\% 20$ disclosure $\% 20$ systems $\% 20$ in $\%$ 20G20\%20countries, \%20prepared $\% 20$ by $\% 20$ the $\% 20$ OECD $\% 2$ 0and\%20the\%20World\%20Bank.pdf?. 2020.

[21] Income and Asset Disclosure. Case Study Illustrations. Directions in Development. Washington: World Bank. doi: 10.1596/978-0-8213-9796-1. 2013. 